\title{
New records of Psocoptera species from Bulgaria
}

\begin{abstract}
Dilian Georgiev
Department of Ecology and Environmental Conservation, University of Plovdiv, 24 Tsar Assen Street, 4000 Plovdiv, Bulgaria, diliangeorgiev@gmail.com $\boldsymbol{\sim}$; https://orcid.org/0000-0003-2885-4895 ¿

Abstract: Four Psocoptera species are reported as new records for Bulgaria: Valenzuela corsicus (Kolbe, 1882) (Ihtimanska Sredna Gora Mts), Reuterella helvimacula (Enderlein, 1901) (Rila Mts), Mesopsocus helveticus Lienhard, 1977 and Hyalopsocus contrarius (Reuter, 1893) (both from Sakar Mts). After this article there are a total of 71 psocid species known from the country.
\end{abstract}

Keywords: Balkan Peninsula, Insecta, new records, Psocoptera

\section{Introduction}

Till now a total of 67 species of Psocoptera have been known to inhabit the territory of Bulgaria (Georgiev, 2021). Here I add four more species collected from various regions to the country check list.

\section{Material and methods}

The study was carried out during the period 2020-2021. All the material was collected by beating the vegetation by a small wooden stick above white plastic container - an empty yogurt box with a size of $16.5 \times 16.5 \times 6 \mathrm{~cm}$. Specimens were then stored in ethanol and after processing, deposited in the collection of the author. Species identifications and taxonomy are based on Lienhard (1998).

\section{Results}

From all the collected materials, four species represent new records for Bulgaria, as follows:
Caeciliusidae

Valenzuela corsicus (Kolbe, 1882). Material examined: 02.12.2021, Ihtimanska Sredna Gora Mts, W of Akandzhievo Village, a meadow with single bushes, near Pinus nigra forest, N42 15 17.3 E24 02 21.5, 336 m a.s.1., 1 , , from Juniperus sp. (Fig. 1, C).

Elipsocidae

Reuterella helvimacula (Enderlein, 1901). Material examined: 26.09.2020, Rila Mts, above Chakar Voyvoda Hut, Pinus peuce and P. mugo forest near the alpine grassland zone, N42 1336.0 E23 37 54.5, 2013 $\mathrm{m}$ a.s.l., 1 , from pine tree brunches overgrown by lichens (Fig. 1, D).

Mesopsocidae

Mesopsocus helveticus Lienhard, 1977. Material examined: 14.11.2021, Sakar Mts, E of Shtit Village, bushes near farmland, N41 4937.7 E26 22 10.0, 220 m a.s.l., 1 , from dry leaves of Sambucus ebulus; 14.11.2021, Sakar Mts, N of Mladinovo Village, 

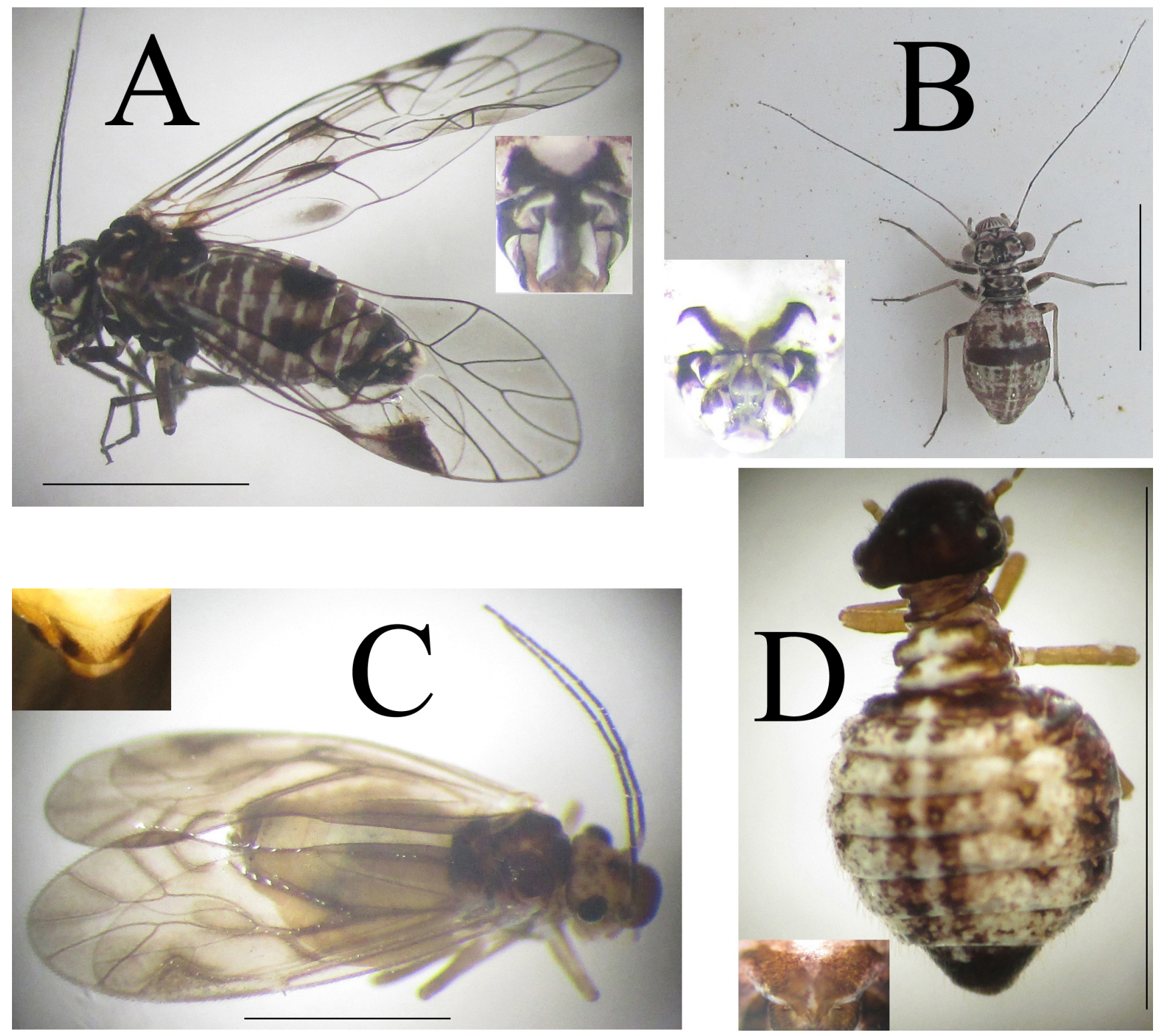

Fig. 1. External views and subgenital plates of the newly recorded Psocoptera species: A - Hyalopsocus contrarius (in glycerin), B - Mesopsocus helveticus (living specimen from the area of Mladinovo Village, subgenital plate of a specimen from the area of Shtit Village), C - Valenzuela corsicus (in glycerin), Reuterella helvimacula (in glycerin). Scale bar approximately 2 $\mathrm{mm}$, related to the whole body of the specimens.

bushes near a road, N41 5707.5 E26 13 53.6, 360 m a.s.l., 1 , from brunches of bushes overgrown by lichens (Fig. 1, B).

\section{Psocidae}

Hyalopsocus contrarius (Reuter, 1893). Material examined: 14.11.2021, Sakar Mts, N of Mladinovo Village, bushes near a road, N41 5707.5 E26 13 53.6,
$360 \mathrm{~m}$ a.s.1., 1 , , from brunches of bushes overgrown by lichens (Fig. 1, A).

\section{Acknowledgements}

I would like to express my gratitude to Dr Charles Lienhard for the discussions about the species identifications. 


\section{References}

Georgiev D. 2021 Two species of Psocoptera (Insecta) as new records to the Bulgarian fauna with a country checklist. Historia naturalis bulgarica 41: $71-75$.

https://doi.org/10.48027/hnb.41.09001 〔
Lienhard C. 1998 Psocoptères euro-méditerranées. Faune de France 83: 1-517. 